
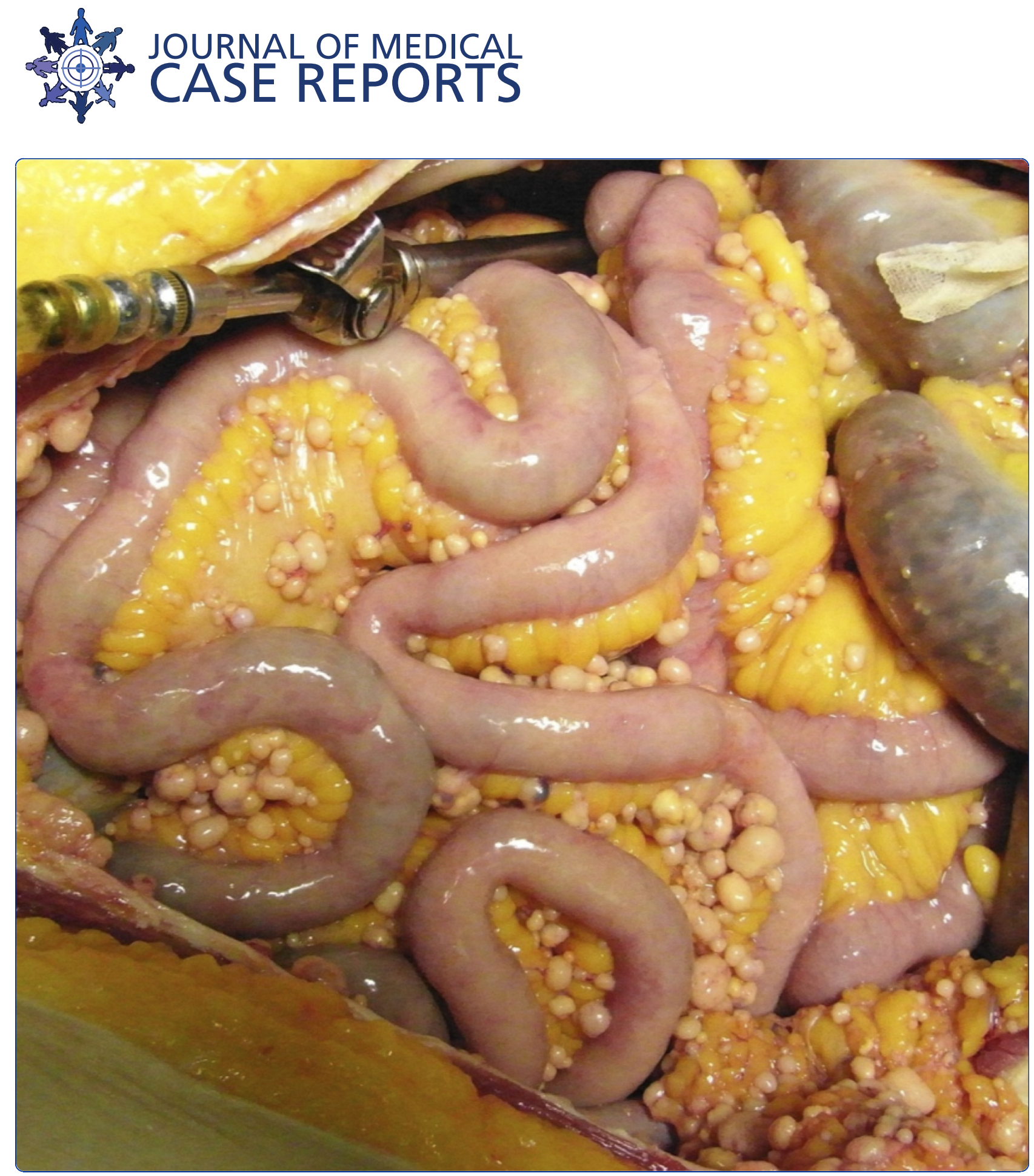

\title{
Peritoneal dissemination of prostate cancer due to laparoscopic radical prostatectomy: a case
} report

Hiyama et al. 


\title{
Peritoneal dissemination of prostate cancer due to laparoscopic radical prostatectomy: a case report
}

Yoshiki Hiyama', Hiroshi Kitamura ${ }^{1 *}$, Satoshi Takahashi ${ }^{1}$, Naoya Masumori ${ }^{1}$, Tetsuya Shindo ${ }^{1}$, Mitsuhiro Tsujiwaki ${ }^{2}$, Tomoko Mitsuhashi ${ }^{2}$ Tadashi Hasegawa ${ }^{2}$ and Taiji Tsukamoto ${ }^{1}$

\begin{abstract}
Introduction: Peritoneal dissemination with no further metastases of prostate cancer is very rare, with only three cases reported in the available literature. We report the first case of iatrogenic peritoneal dissemination due to laparoscopic radical prostatectomy.

Case Presentation: A 59-year-old Japanese man underwent laparoscopic radical prostatectomy for clinical T2bNOMO prostate cancer, and the pathological diagnosis was pT3aNO Gleason 3+4 adenocarcinoma with a negative surgical margin. Salvage radiation therapy was performed since his serum prostate-specific antigen remained at a measurable value. After the radiation, he underwent castration, followed by combined androgen blockade with estramustine phosphate and dexamethasone as each treatment was effective for only a few months to a year. Nine years after the laparoscopic radical prostatectomy, computed tomography revealed a peritoneal tumor, although no other organ metastasis had been identified until then. He died six months after the appearance of peritoneal metastasis. An autopsy demonstrated peritoneal dissemination of the prostate cancer without any other metastasis.
\end{abstract}

Conclusion: Physicians should take into account metastasis to unexpected sites. Furthermore, we suggest that meticulous care be taken not to disseminate cancer cells to the peritoneum during laparoscopic radical prostatectomy.

\section{Introduction}

Peritoneal dissemination with no further metastases of prostate cancer is very rare with, to the best of our knowledge, only three cases reported in the available literature. There has not yet been a report of a patient undergoing surgical treatment that might have resulted in iatrogenic dissemination. We report the first case of iatrogenic peritoneal dissemination due to laparoscopic radical prostatectomy (LRP).

\section{Case presentation}

A 59-year-old Japanese man presented to our urology clinic with lower urinary tract symptoms. His serum prostate-specific antigen (PSA) level was $9.5 \mathrm{ng} / \mathrm{mL}$. A digital rectal examination revealed a hard induration of his prostate. He had no personal or familial history of

\footnotetext{
* Correspondence: hkitamu@sapmed.ac.jp

'Department of Urology, Sapporo Medical University School of Medicine, Sapporo, Japan

Full list of author information is available at the end of the article
}

malignant disease. A prostate biopsy was performed and showed Gleason score 3+4 adenocarcinoma of the prostate. Computerized tomography $(\mathrm{CT})$ and bone scintigraphy showed no metastasis. He was referred to our Department of Urology for treatment of cT2bN0M0 prostate cancer, and underwent LRP. The operation was performed with a transperitoneal approach. The pathological diagnosis was pT3aN0 Gleason score 4+4 adenocarcinoma with a positive surgical margin.

After the operation, his PSA level dropped to $0.7 \mathrm{ng} /$ $\mathrm{mL}$ at its lowest, and so salvage radiation therapy with 50 Gy was carried out. His serum PSA level initially dropped to $0.5 \mathrm{ng} / \mathrm{mL}$ but began to increase, to $3.5 \mathrm{ng} /$ $\mathrm{mL}$, shortly after. Medical castration was then started. The therapy was effective for 24 months, after which he needed additional anti-androgen agents (bicalutamide and flutamide) and estramustine phosphate because of an increase in his PSA level. Sixty-six months after the prostatectomy (PSA $76.3 \mathrm{ng} / \mathrm{mL}$ ) dexamethasone was administered, and provided the minimal PSA level, 0.58
Ciomed Central

() 2011 Hiyama et al; licensee BioMed Central Ltd. This is an Open Access article distributed under the terms of the Creative Commons Attribution License (http://creativecommons.org/licenses/by/2.0), which permits unrestricted use, distribution, and reproduction in any medium, provided the original work is properly cited. 
$\mathrm{ng} / \mathrm{mL}, 18$ months after the initial administration. However, his PSA level increased again, so the endothelin receptor antagonist was replaced by dexamethasone for 12 months with no effect on his PSA level. Thereafter dexamethasone was administered again, and his PSA decreased from $340 \mathrm{ng} / \mathrm{mL}$ to $118 \mathrm{ng} / \mathrm{mL}$.

After that, his PSA level continued to increase without any metastasis visible on CT or bone scans. Our patient could not undergo chemotherapy with docetaxel because of complications with heart failure and interstitial pulmonary disease. At age 69, 114 months after the LRP, CT showed a peritoneal tumor that was considered to be a peritoneal metastasis (Figure 1). His PSA level was $168 \mathrm{ng} / \mathrm{mL}$, and no other organ metastasis was found. Five months later, metastases to the mesentery were revealed by CT. The peritoneal metastases progressed with a large amount of ascites, and our patient died 120 months after the LRP.

An autopsy revealed $4000 \mathrm{ml}$ of clear yellow ascites and numerous nodules in his peritoneum, mesentery and omentum (Figure 2). These were pathologically diagnosed as dissemination of prostate cancer. No other metastasis was detected in any organ in the pathological evaluation. There was no port-site metastasis, during follow-up or at autopsy.

\section{Discussion}

Metastases from prostate cancer to the bone, lymph nodes and lung are common events, but peritoneal metastasis is very rare and seldom reported in the literature. Even at autopsy, peritoneal metastasis is unusual, whereas bone (90\%), lung (46\%), liver (25\%), pleural

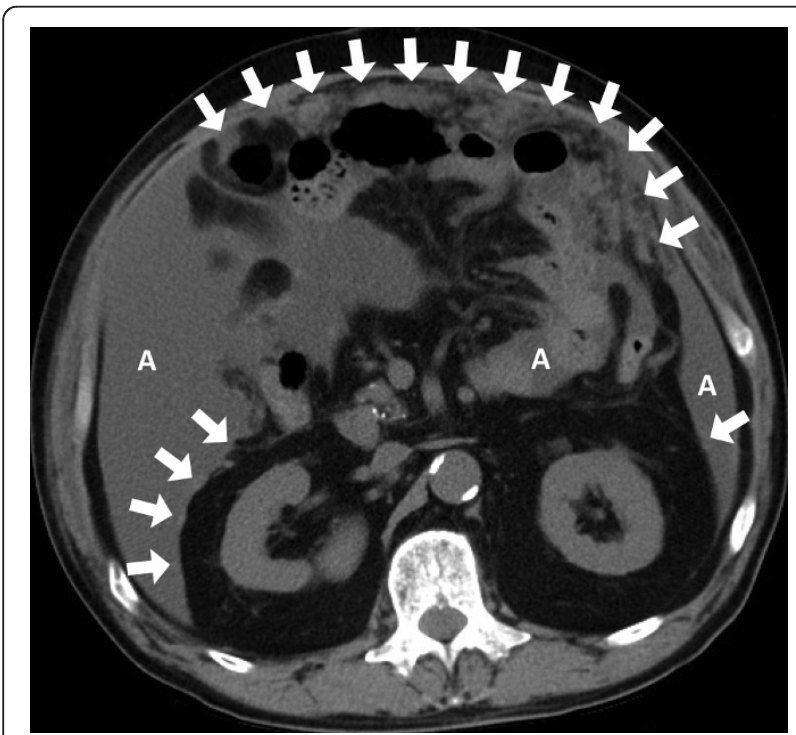

Figure 1 An abdominal CT scan shows mesenteric metastases (arrows) and ascites (A) due to peritoneal dissemination.

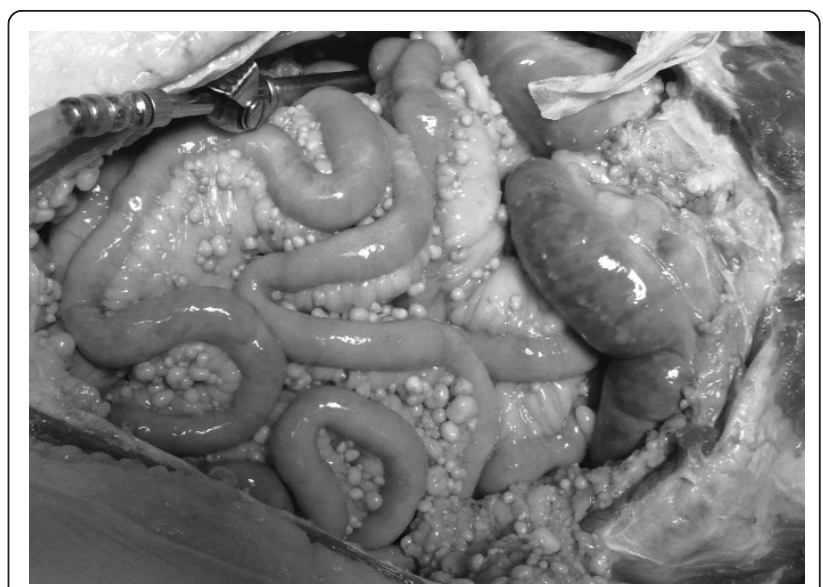

Figure 2 Multiple nodules in the mesentery at autopsy

(21\%) and adrenal (13\%) metastases are reported in some large autopsy series [1]. Only three cases with peritoneal metastasis from prostate cancer have been reported (Table 1) [2-4]. Although these three cases had no opportunity for tumor implantation, our patient might have incurred iatrogenic dissemination to the peritoneum during the LRP. To our knowledge, this is the first case of iatrogenic peritoneal dissemination due to LRP. The main causes of such metastases appear to be tumor behavior and laparoscopy-related factors [5,6], including gas ambience [7], surgical manipulation [6] and overuse of ultrasonic scissors [8]. Alternatively, the dissemination may have been due to poor surgical technique, since this was only the second case of LRP in our institute. Lee et al. reported that poor technique increased port-site metastasis risks [9] and growing experience decreases this incidence [10]. However, the possible existence of peritoneal metastases at the LRP cannot be ruled out, since his serum PSA level did not fall under the lowest measuring limit during the local therapies.

The pathological diagnoses of the previous three cases were Gleason 4 and/or 5 adenocarcinoma with or without mucinous adenocarcinoma (Table 1). Two of them demonstrated good responses to hormone therapy [2,3], and the combination of docetaxel with estramustine phosphate was effective in the other case [4]. Our patient experienced 120-month survival after the initial treatment, although no therapy was available without dexamethasone when the peritoneal metastasis was detected. Thus the standard strategy should be considered as a treatment for peritoneal metastasis from prostate cancer.

\section{Conclusion}

Peritoneal dissemination of prostatic carcinoma is a very rare occurrence. Meticulous procedures during LRP 
Table 1 Summary of reported cases of peritoneal metastasis of prostate cancer

\begin{tabular}{|c|c|c|c|c|c|c|c|c|}
\hline Authors & Age & $\begin{array}{l}\text { Initial } \\
\text { PSA } \\
\text { (ng/ } \\
\mathrm{mL} \text { ) }\end{array}$ & Gleason score & $\begin{array}{l}\text { Initial } \\
\text { TNM }\end{array}$ & $\begin{array}{l}\text { Treatment before } \\
\text { detection of the peritoneal } \\
\text { metastasis }\end{array}$ & $\begin{array}{l}\text { PSA at the } \\
\text { diagnosis of } \\
\text { peritoneal } \\
\text { metastasis (ng/ } \\
\mathrm{mL} \text { ) }\end{array}$ & $\begin{array}{l}\text { Treatment after } \\
\text { the diagnosis of } \\
\text { peritoneal } \\
\text { metastasis }\end{array}$ & $\begin{array}{l}\text { Follow-up after } \\
\text { the diagnosis of } \\
\text { peritoneal } \\
\text { metastasis }\end{array}$ \\
\hline $\begin{array}{l}\text { Kehinde } \\
\text { et al. [2] }\end{array}$ & 76 & 365 & $\begin{array}{l}4+4, \text { mucinous } \\
\text { adenocarcinoma }\end{array}$ & $\begin{array}{l}\text { T3(?) } \\
\text { NOM1 }\end{array}$ & - & 365 & Hormone therapy & 18 months, AED \\
\hline $\begin{array}{l}\text { Brehmer } \\
\text { et al. [3] }\end{array}$ & 75 & 42 & $4+5$ & T3N0M1 & - & 42 & Hormone therapy & 14 months, AED \\
\hline $\begin{array}{l}\text { Zagouri } \\
\text { et al. [4] }\end{array}$ & 75 & 33 & $4+5$ & TXNOMO & $\begin{array}{l}\text { Hormone therapy for } 72 \\
\text { months }\end{array}$ & 74 & $\begin{array}{l}\text { Docetaxel + } \\
\text { estramustine } \\
\text { phosphate }\end{array}$ & 18 months, AED \\
\hline $\begin{array}{l}\text { Present } \\
\text { case }\end{array}$ & 69 & 9.5 & $4+4$ & T3aNOMO & $\begin{array}{l}\text { Radical prostatectomy, } \\
\text { salvage radiotherapy, and } \\
\text { hormone therapy for } 89 \\
\text { months }\end{array}$ & 168 & Palliative & 6 months, DOD \\
\hline
\end{tabular}

should be performed to avoid a dissemination of cancer cells to the peritoneum. The treatment should be performed in accordance with the standard strategy for prostate cancer, including hormone therapy and chemotherapy.

\section{Consent}

Written informed consent was obtained from the patient for publication of this case report and accompanying images. A copy of the written consent is available for review by the Editor-in-Chief of this journal.

\section{Abbreviations}

CT: computerized tomography; LRP: laparoscopic radical prostatectomy; PSA: prostate-specific antigen.

\section{Author details}

'Department of Urology, Sapporo Medical University School of Medicine, Sapporo, Japan. ${ }^{2}$ Department of Surgical Pathology, Sapporo Medical University Hospital, Sapporo, Japan.

\section{Authors' contributions}

HY, HK, ST, NM, TS and TT were involved in conception, design and interpretation. HY and HK wrote the manuscript. MT, TM and TT performed the histological examination and provided the histopathological images. All authors read and approved the final version submitted.

\section{Competing interests}

The authors declare that they have no competing interests.

Received: 24 January 2011 Accepted: 5 August 2011

Published: 5 August 2011

\section{References}

1. Bubendorf L, Schopfer A, Wagner U, Sauter G, Moch H, Willi N, Gasser TC, Mihatsch MJ: Metastatic patterns of prostate cancer: an autopsy study of 1,589 patients. Hum Pathol 2000, 31(5):578-583.

2. Kehinde EO, Abdeen SM, Al-Hunayan A, Ali Y: Prostate cancer metastatic to the omentum. Scand J Urol Nephrol 2002, 36(3):225-227.

3. Brehmer B, Makris A, Wellmann A, Jakse G: [Solitary peritoneal carcinomatosis in prostate cancer]. Aktuelle Urol 2007, 38(5):408-409.

4. Zagouri F, Papaefthimiou M, Chalazonitis AN, Antoniou N, Dimopoulos MA, Bamias A: Prostate cancer with metastasis to the omentum and massive ascites: a rare manifestation of a common disease. Onkologie 2009, 32(12):758-761.

5. Wittich P, Marquet RL, Kazemier G, Bonjer HJ: Port-site metastases after CO (2) laparoscopy. Is aerosolization of tumor cells a pivotal factor? Surg Endosc 2000, 14(2):189-192.

6. Tsivian A, Sidi AA: Port site metastases in urological laparoscopic surgery. J Urol 2003, 169(4):1213-1218.

7. Kuntz C, Wunsch A, Bodeker C, Bay F, Rosch R, Windeler J, Herfarth C: Effect of pressure and gas type on intraabdominal, subcutaneous, and blood $\mathrm{pH}$ in laparoscopy. Surg Endosc 2000, 14(4):367-371.

8. lacconi P, Bendinelli C, Miccoli P, Bernini GP: Re: A case of Cushing's syndrome due to adrenocortical carcinoma with recurrence 19 months after laparoscopic adrenalectomy. Re: Re: A case of Cushing's syndrome due to adrenocortical carcinoma with recurrence 19 months after laparoscopic adrenalectomy. J Urol 1999, 161(5):1580-1581.

9. Lee SW, Southall J, Allendorf J, Bessler M, Whelan RL: Traumatic handling of the tumor independent of pneumoperitoneum increases port site implantation rate of colon cancer in a murine model. Surg Endosc 1998, 12(6):828-834.

10. Lee SW, Gleason NR, Bessler M, Whelan RL: Port site tumor recurrence rates in a murine model of laparoscopic splenectomy decreased with increased experience. Surg Endosc 2000, 14(9):805-811.

doi:10.1186/1752-1947-5-355

Cite this article as: Hiyama et al.: Peritoneal dissemination of prostate cancer due to laparoscopic radical prostatectomy: a case report. Journal of Medical Case Reports 2011 5:355.

\section{Submit your next manuscript to BioMed Central and take full advantage of:}

- Convenient online submission

- Thorough peer review

- No space constraints or color figure charges

- Immediate publication on acceptance

- Inclusion in PubMed, CAS, Scopus and Google Scholar

- Research which is freely available for redistribution 